\title{
Stage IVB Bladder Cancer
}

National Cancer Institute

\section{Source}

National Cancer Institute. Stage IVB Bladder Cancer. NCI Thesaurus. Code C9368.

Stage IV includes $\mathrm{T} 4 \mathrm{~b}, \mathrm{NO}, \mathrm{MO} /$ any $\mathrm{T} \mathrm{NI}, \mathrm{MO}$ / any $\mathrm{T} \mathrm{N} 2 \mathrm{MO}$, / any $\mathrm{T} \mathrm{N} 3 \mathrm{MO}$ / any $\mathrm{T}$ any $\mathrm{N}$ M1 : T4b: Tumor invades the pelvic wall, abdominal wall. N1: Metastasis in a single lymph node, $2 \mathrm{~cm}$ or less in greatest dimension. N2: Metastasis in a single lymph node, more than $2 \mathrm{~cm}$ but not more than $5 \mathrm{~cm}$ in greatest dimension; or multiple lymph nodes, none more than $5 \mathrm{~cm}$ in greatest dimension. N3: Metastasis in a lymph node more than $5 \mathrm{~cm}$ in greatest dimension. M1: Distant metastasis. 